\title{
НУКЛЕОФИЛЬНОЕ ЗАМЕЩЕНИЕ АЛКОКСИГРУПП АМИНАМИ - ЭФФЕКТИВНЫЙ МЕТОД МОДИФИКАЦИИ ПОЛИКОНДЕНСИРОВАННЫХ СОЕДИНЕНИЙ
}

\author{
А.Е. Щекотихинн, \\ ${ }^{1}$ Научно-исследовательский институт по изысканию новых антибиотиков \\ им. Г. Ф. Гаузе, 119021, Россия, Москва, ул. Большая Пироговская, д. 11, стр. 1. \\ ${ }^{2}$ Российский химико-технологический университет им. Д. И. Менделеева, \\ 125190, Россия, Москва, Миусская пл., д. 9.
}

DOI: 10.19163/MedChemRussia2021-2021-17

E-mail: shchekotikhin@mail.ru

Нуклеофильное замещение является одним из важных методов синтеза лекарственных препаратов [1]. Традиционно, в качестве нуклеофугов, подходящих для ароматического нуклеофильного замещения, рассматриваются атомы галогенов, эфиры сульфокислот, нитро- или сульфогруппы, активированные электроноакцепторными заместителями.

В результате систематического исследования химических свойств производных 4,11-диметоксинафто[2,3-f]индол-5,10-диона было установлено, что метоксигруппы в пери-положениях хиноидного ядра в мягких условиях и с высокими выходами замещаются на остатки первичных и вторичных аминов [2]. Дальнейшие исследования показали, что аналогичная реакция хорошо протекает и для других представителей линейных поликонденсированных гетероаренантрацендионов [3-5]. На основе этой реакции разработана эффективная методология трансформации гидроксигрупп в пери-положениях к карбонильным группам гетероаренантрацендионов, которая через промежуточные алкоксипроизводные, позволяет получать соответствующие аминопроизводные. Этот подход использован для препаративного синтеза аминопроизводных гетероаренантрацендионов, обладающих высокой биологической активностью [6-8].

Разработанная методология может быть успешно применена для модификации и других поликонденсированных соединений. Так, этот способ апробирован для трансформации гидроксигрупп гелиомицина в соответствующие аминоэтиламинопроизводные этого антибиотика, которые показали высокую аффинность к различным вторичным структурам нуклеиновых кислот, например к і-мотивам [9].

\section{Литература}

[1] R. W. Dugger etal. Organic Process Research \& Development 2005, 9, 3, 253.

[2] A. E. Shchekotikhin etal. Bioorg. Med. Chem. 2006, 5241.

[3]A. E. Shchekotikhin etal. Bioorg. Med. Chem. 2009, 1861.

[4] N. S. Ilyinsky et al. Eur. J. Med. Chem. 2014, 85, 605.

[5] A. E. Shchekotikhin etal. Eur. J. Med. Chemistry 2011, 423.

[6] A. S. Tikhomirov etal. Chem. Heterocycl. Compd. 2016, 52(10), 797.

[7] A. S. Tikhomirov et al. Eur. J. Med. Chem. 2018, 159, 58.

[8] G. Miglietta etal. J. Med. Chem. 2017, 60, 9448.

[9] A.S. Tikhomirov etal. J. Nat. Prod. 2021, 84 (5), 1617. 